\title{
MENINGKATKAN MINAT BELAJAR SISWA DALAM PEMBELAJARAN PENDIDIKAN JASMANI OLAHRAGA DAN KESEHATAN MELALUI METODE BERMAIN PADA KELAS VIII-4 SEKOLAH MENENGAH PERTAMA NEGERI 2 BATUSANGKAR.
}

\author{
Ali Asmi ${ }^{1}$, Hendri Neldi ${ }^{2}$, Khairuddin ${ }^{3}$ \\ ${ }^{1}$ Program Studi Pendidikan Jasmani Kesehatan dan Rekreasi, Fakultas Ilmu Keolahragaan, \\ Universitas Negeri Padang, Jalan Prof. DR. Hamka Air Tawar Barat, Padang, 25132, Indonesia \\ ${ }^{2}$ Program Studi Pendidikan Jasmani Kesehatan dan Rekreasi, Fakultas Ilmu Keolahragaan, \\ Universitas Negeri Padang, Jalan Prof. DR. Hamka Air Tawar Barat, Padang, 25132, Indonesia \\ ${ }^{3}$ Program Studi Pendidikan Jasmani Kesehatan dan Rekreasi, Fakultas Ilmu Keolahragaan, \\ Universitas Negeri Padang, Jalan Prof. DR. Hamka Air Tawar Barat, Padang, 25132, Indonesia
}

\section{E- Mail: aliasmi@fik.unp.ac.id $^{1}$, $\underline{\text { hendrineldi@fik.unp.ac.id }}^{2}$, $\underline{\text { khairuddin@fik.unp.ac.id }}^{3}$}

\begin{abstract}
Abstrak
Latar belakang penelitian ini adalah rendahnya minat belajar siswa dalam proses pembelajaran Penjasorkes. Apakah dengan menggunakan metode bermain dapat meningkatkan minat belajar siswa dalam pembelajaran Penjasorkes dikelas VIII-4 SMP Negeri 2 Batusangkar?. Tujuan penelitian ini adalah untuk mengetahui manfaat dari metode bermain dalam menarik minat belajar siswa untuk meningkatkan pembelajaran Penjasorkes.

Jenis penelitian yang digunakan adalah penelitian tindakan kelas (PTK) yang terdiri dari siklus I dan siklus II. Tiap siklus terdiri dari perencanaan, pelaksanaan tindakan, observasi dan refleksi. Penelitian ini dilakukan di SMP Negeri 2 Batusangkar dengan subjek penelitian kelas VIII-4 dengan jumlah siswa 33 orang. Teknik pengumpulan data dilaksanakan melalui lembar observasi dianalisis secara deskripsi dengan teknik persentase dan angket dianalisis menggunakan sistem penskoran skala Likert.

Berdasarkan hasil penelitian yang telah dilakukan dapat disimpulkan melalui hal-hal sebagai berikut: (1) Aktivitas gerak siswa meningkat, peningkatan gerak siswa mencapai $75,7 \%$, (2) Kerjasama siswa dalam kegiatan pembelajaran meningkat mencapai $78,8 \%$ serta disiplin siswa meningkat yaitu mencapai 90,9\%, (3) Analisis minat belajar siswa menunjukan bahwa kategori minat siswa dalam proses pembelajaran adalah sangat tinggi. Dengan demikian pembelajaran Penjasorkes melalui metode bermain dapat meningkatkan minat belajar siswa dikelas VIII-4 SMP Negeri 2 Batusangkar.
\end{abstract}

\section{Kata Kunci : Minat Belajar, Metode Bermain}

\section{PENDAHULUAN}

Berbagai kemajuan dalam peradaban manusia sampai saat ini tidak pernah lepas dari dunia pendidikan. Hal ini tentunya beralasan karena melalui pendidikan dapat tercipta Sumber Daya Manusia (SDM) yang mampu mengoptimalkan berbagi sumber daya yang ada untuk dimanfaatkan dalam kehidupan.

Dengan diterbitkannya Undang-Undang Republik Indonesia tentang Sistem Pendidikan Nasional dan Perturan Pemerintah tentang Standar Nasional Pendidikan, diharapkan memberikan peluang untuk menyempurnakan kurikulum yang komprehensif (luas dan lengkap) dalam rangka mencapai tujuan pendidikan nasional.
Departemen Pendidikan Nasional Tahun 2003 menjelaskan bahwa "Pendidikan jasmani adalah proses pendidikan yang memanfaatkan aktivitas jasmani yang direncanakan secara sistematik yang bertujuan untuk meningkatakan individu secara organik, neuromuskuler, perseptual, kognitif dan emosional dalam kerangka system pendidikan nasional".

Melalui pembelajaran Penjasorkes dalam bentuk bermain ini, diharapkan siswa dapat berpatisipasi aktif yang pada akhirnya mereka memiliki pengalaman belajar yang bermakna, menarik dan menyenangkan, sedangkan guru berperan sebagai fasilitator dan motivator.

Berdasarkan hasil observasi yang peneliti lakukan dilapangan menunjukan bahwa pelaksanaan pengajaran Penjasorkes kelas VIII-4 
di SMP Negeri 2 Batusangkar belum sesuai dengan ketuntasan kurikulum KTSP.

Pelaksanaan Penjasorkes seharusnya menyenangkan bagi siswa tapi kenyataannya siswa terlihat kurang berminat dalam pelaksanaan pembelajaran seperti: siswa mengobrol dengan temannya sendiri, tidak serius, malas-malasan dalam mengerjkan kegiatan yang diberikan oleh guru dilapangan.

Kualitas pembelajaran tergolong rendah dan gaya mengajar yang dilakukan guru dalam mengajar dilapangan, cenderung tradisional atau hanya menggunakan satu gaya mengajar saja. Guru dalam perakteknya kurang kreatif dalam memberikan model pembelajaran, hanya menekankan hasil akhir tanpa memperhatikan proses pembelajaran.

Minat dalam belajar perlu mendapatkan perhatian khusus karena minat merupakan salah satu faktor pendukung atau penunjang keberhasilan dalam belajar. Arikunto (dalam Meilinda 2009:6) mengatakan dengan adanya minat dan perhatian siswa pada pelajaran yang diberikan, maka isi dari pelajaran akan diserap dengan baik.

Sebaliknya tanpa adanya minat atau perhatian terhadap apa yang diberikan guru tidak akan didengar apalagi dikuasai, bila individu sudah berminat terhadap sesuatu dengan sendirinya akan tertarik kepada objek tersebut bahkan jiwanya akan dicurahkan kepada apa yang sedang diperhatikannya.

Siswa yang berminat terhadap pelajaran akan tampak terdorong dan selalu tekun dalam belajar, berbeda dengan siswa yang sikapnya hanya menerima pelajaran. Jika minat seseorang tinggi dalam belajar, maka ia cendrung aktif dalam belajar dan akan menguasai materi pelajaran.

Siswa akan terdorong untuk belajar apabila mereka memiliki minat untuk belajar. Oleh sebab itu, meningkatkan minat belajar siswa merupakan salah satu teknik dalam mengembangkan motivasi siswa dan meningkatkan hasil belajar. Ada berberapa hal yang dapat mempengaruhi minat belajar dan untuk mempengaruhi minat siswa tersebut maka seseorang pendidik harus mampu mengubah proses belajar yang membosankan menjadi pengalaman belajar yang mengairahkan atau menyenangkan. Skinner (dalam Wijaya Kusumah 2012:297) mengungkapkan sebagai berikut: a. Materi yang dipelajari haruslah menjadi menarik dan menimbulkan susana yang baru. Misalnya dalam bentuk permainan, diskusi atau pemberian tugas diluar sekolah sebagai variasi kegiatan belajar.

b. Materi pelajaran menjadi lebih menarik apabila siswa mengetahui tujuan dari pelajaran itu.

c. Minat siswa terhadap pelajaran dapat dibangkitkan dengan variasi metode yang digunakan.

d. Minat siswa juga bisa dibangkitkan kalau mereka mengetahui manfaat atau kegunaan dari pelajaran itu bagi dirinya.

Selanjutnya Abdul Majid (2012:226) mengatakan bahwa masalah-masalah belajar dapat digolongkan atas:

a. Sangat cepat dalam belajar, yaitu muridmurid yang tampaknya memiliki bakat akademik yang cukup tinggi, memili IQ 130 atau lebih.

b. Keterlambatan akademik, yaitu muridmurid yang tampaknya memiliki inteligensi normal tetapi tidak dapat memanfaatkannya secara baik.

c. Lambat belajar, yaitu murid-murid yang tampak memiliki kemampuan yang kurang memadai. Mereka memiliki IQ sekitar 70-90 sehingga perlu dipertimbangkan untuk mendapatkan bantuan khusus.

d. Penampakan kelas, yaitu murid-murid yang umur, kemampuan, ukuran dan minat-minat sosial yang terlalu besar/terlalu kecil untuk kelas yang ditempatinya.

e. Kurang motif dalam belajar, yaitu muridmurid yang kurang semangat dalam belajar, mereka tampak jera dan malas.

f. Sikap dan kebiasaan buruk, murid-murid yang kegiatan atau perbuatan belajarnya berlawanan atau tidak sesuai dengan seharusnya.

g. Kehadiran di Madrasah, murid-murid yang sering tidak hadir atau menderita sakit dalam waktu yang cukup lama sehingga kehilangan sebagian besar kegiatan belajarnya.

Guru yang akrab dengan murid, menghargai usaha-usaha murid dalam belajar dan suka memberi petunjuk jika murid menghadapi kesulitan, hal ini akan dapat menimbulkan 
perasaan sukses dalam diri muridnya dan akan menumbuhkan keyakinan dalam diri murid. Guru yang memiliki penilaian diri yang positif akan ditiru oleh murid-muridnya juga akan memiliki penilaian diri yang positif terhadap dirinya sendiri.

Jadi, guru yang kurang akrab dan kurang menghargai usaha-usaha murid maka murid akan merasa kurang diperhatikan dan akan mengakibatkan murid itu malas belajar atau kurangnya minat belajar sehingga anak tersebut akan mengalami kesulitan didalam belajar.

Achmad Patusari (2012:18-19) menjelaska bahwa manfaat pendidikan jasmani dan olahraga disekolah secara umum mencangkup sebagai berikut:

a. Memenuhi kebutuhan anak akan gerak.

b. Mengenalkan anak pada lingkungan dan potensi dirinya.

c. Menanamkan dasar-dasar keterampilan yang berguna.

d. Menyalurkan energi yang berlebih.

e. Merupakan peroses pendidikan secara serampak baik fisik, mental maupun emosional.

Bermain merupakan suatu kegiatan yang penting bagi kehidupan anak, melalui bermain akan menimbulkan kesenangan, kelincahan dan kesejahterahan bagi anak sehingga anak akan bergairah dan memudahkan anak melakukan kegiatan tanpa paksaan. Jadi dengan bermain dapat miningkatkan minat anak dalam melakukan suatu kegiatan.

\section{METODE}

Setting dalam penelitian ini meliputi tempat penelitian, waktu penelitian dan siklus penelitian tindakan kelas (PTK). Setting penelitian dapat dijelaskan sebagai berikut:

Penelitian tindakan kelas ini dilaksanakan di SMP N 2 Batusangkar untuk mata pelajaran Penjasorkes. Sebagai subjek dalam penelitian ini adalah siswa kelas VIII-4 tahun pelajaran 2013/2014 dengan jumlah siswa sebanyak 33 siswa, terdiri dari 18 siswa laki-laki dan 15 siswa perempuan.

Penelitian ini dimulai pada tanggal $23 \mathrm{Mei}$ sampai tanggal 6 juni 2014. Penentuan waktu penelitian ini, mengacu pada kelender akademik sekolah, karena penelitan tindakan kelas memerlukan berberapa siklus yang membutuhkan proses belajar mengajar yang efektif dikelas.

\section{Siklus Penelitian Tindakan Kelas (PTK)}

Penelitian tindakan kelas ini dilaksanakan melalui dua siklus untuk melihat peningkatan minat belajar siswa dalam mengikuti pelajaran Penjasorkes melalui metode bermain yang dimodifikasi. Metode penelitian yang dilakukan dalam penelitian ini adalah metode Penelitian Tindakan Kelas (PTK) model Kurt Lewin. Konsep pokok PTK menurut Kurt Lewin terdiri dari empat komponen, yaitu: perencanaan (planning), tindakan (acting), pengamatan (observasing) dan refleksi (reflecting). Hubungan keempat komponen tersebut dipandang sebagai satu siklus.

Dalam penelitian tindakan kelas yang menjadi subjek penelitian adalah siswa kelas VIII-4 yang terdiri dari 33 siswa terdiri dari 18 siswa laki-laki dan 15 siswa perempuan.

Sumber data dalam penelitian ini terdiri dari berberapa sumber yaitu siswa, guru dan teman sejawat.

1. Siswa, untuk mendapatkan data tentang minat belajar siswa dalam peroses belajar mengajar.

2. Guru, untuk melihat tingkat keberhasilan implementasi pembelajaran melalui metode bermain.

3. Teman sejawat dan kolaborator, teman sejawat dan kolaborator dimaksudkan sebagai sumber data untuk melihat implementasi PTK secara lengkap, mencangkup semua hal yang diperlukan, baik dari sisi siwa maupun guru.

\section{A. Alat dan Teknik Pengumpulan Data}

\section{Alat Pengumpulan Data}

Alat penelitian ini terdiri dari berberapa macam yaitu:
a. Observasi
b. Wawancara
c. Dekumentasi
d. Kuesioner
e. Diskusi

\section{Teknik Pengumpulan Data}

Teknik pengumpulan data dalam penelitian ini adalah observasi, wawancara, dokumentasi.

\section{a. Observasi}

Penulis mencetak kegiatan yang dilakukan anak berdasarkan indikator, aspek yang diamati guru melalui pedoman ini adalah yang berkaitan dengan paroses belajar mengajar, ini digunakan untuk mengetahui kesesuian pelaksanaan tindakan dengan rencana yang telah disusun sebelumnya.

Meningkatkan Minat Belajar Siswa Dalam Pembelajaran ....35 Sefriadiansyah $^{1}$, Eldawaty ${ }^{2}$ 


\section{b. Wawancara}

Penulis menanyakan berberapa pertanyaan kepada anak diakhir pembelajaran tentang kegiatan yang telah mereka lakukan menggunakan panduan wawancara untuk mengetahui pendapat atau sikap siswa tentang pembelajaran Penjasorkes melalui metode bermain.

\section{c. Dokumentasi}

Penulis mendokumentasi berupa lembaran observasi, foto maupun video yang diambil sewaktu pembelajaran sedang berlangsung.

\section{d. Kuesioner}

Untuk mengetahui pendapaat atau sikap dan teman sejawat tentang pembelajaran Penjasorkes melalui metode bermain.

\section{e. Diskusi}

Diskusi antara guru, teman sejawat dan kolaborator untuk refleksi hasil siklus penelitian tindakan kelas (PTK).

\section{B. Indikator Kinerja}

Dalam PTK ini yang akan dilihat indikator kinerja selain siswa adalah guru karena guru merupkan fasilitator yang sangat berpengaruh terhadap kinerja siswa.

\section{Siswa}

Observasi: keaktifan siswa dalaam proses belajar mengajar dalam pembelajaran Penjasorkes dilapangan.

2. Guru

a. Dokumentasi: kehadiran siswa.

b. Observasi: hasil observasi.

\section{Analisis Data}

Data yang diperoleh dari hasil observasi dianalisi secara derkriptif. Setiap kegiatan pembelajaran yang dilakukan merupakan bahan yang menentukan tindakan berikutnya. Disamping itu, seluruh data digunakan untuk mengambil kesimpulan dan tindakan yang dilakukan. Data yang berhasil disimpulkan kemudian dianalisi dengan menggunakan teknik analisis deskriptif dengan meggunakan teknik persentase untuk melihat kecederungan yang terjadi dalam kegiatan pembelajar. Dengan menggunakan rumus yang dikemukakan oleh Hariadi dalam Ria Santosa (2009:43) seperi berikut:

$$
p=\frac{\mathrm{F}}{\mathrm{N}} \times 100 \%
$$

Keterangan: $\mathrm{P}=$ Persentase.

$\mathrm{F}=$ Jumlah anak yang terlibat dalam setiap aspek.
$\mathrm{N}=$ Jumlah anak yang hadir.

Selanjutnya hasil pengukuran minat belajar siswa diolah dengan menggunakan sistem penskoran skala Likert dengan menggunakan empat pilihan agar jelas minat responden. Untuk menafsirkan hasil pengukuran digunakan kriteria sebagai berikut:

Tabel 1. Kategori Skor untuk Setiap Butir Pernyataan

\begin{tabular}{|c|c|}
\hline RESPONDEN & KATEGORI SKOR \\
\hline Sangat setuju & 4 \\
\hline Setuju & 3 \\
\hline Tidak setuju & 2 \\
\hline Sangat tidak setuju & 1 \\
\hline
\end{tabular}

Skor tertinggi untuk instrumen tersebut adalah 15 butir x $4=60$ dan skor terendah 15 butir $\mathrm{x} 1=15$. Skor ini dikualifikasikan menjadi empat kategori minat yaitu sangat tinggi (sangat baik), tinggi (baik), rendah (kurang) dan sangat rendah (sangat kurang). Berdasarkan kategori tersebut dapat ditentukan minat individu siswa. Penetuan kategori hasil pengukuran minat dapat dilihat pada tabel berikut ini:

Tabel 2. Kategori Minat Siswa untuk 15 Butir Pernyataan

dengan Rentang Skor 15 Sampai 60

\begin{tabular}{|c|c|c|}
\hline No & Skor siswa & Kategori minat \\
\hline 1 & $\begin{array}{c}\text { Lebih dari } \\
48\end{array}$ & Sangat tinggi/sangat baik \\
\hline 2 & $\begin{array}{c}42 \text { sampai } \\
47\end{array}$ & Tinggi/baik \\
\hline 3 & $\begin{array}{c}30 \text { sampai } \\
41\end{array}$ & Rendah/kurang \\
\hline 4 & $\begin{array}{c}\text { Kurang dari } \\
30\end{array}$ & Sangat rendah/sangat kurang \\
\hline
\end{tabular}

\section{Prosedur Penelitian}

Prosedur pelaksanaan penelitian ini akan dilakukan secara bersiklus yaitu siklus I dan siklus II. Setelah selesai siklus I, dilanjutkan dengan siklus II. Siklus II sangat ditentukan oleh indikator keberhasilan siklus I. Masing-masing siklus terdiri dari satu pertemuan.

Siklus merupakan ciri khas dari penelitian tindakan kelas (PTK). Penelitian tindakan kelas ini mengacu kepada model Kurt Lewin. Konsep

Meningkatkan Minat Belajar Siswa Dalam Pembelajaran .....36 Sefriadiansyah ${ }^{1}$, Eldawaty ${ }^{2}$ 
pokok penelitian tindakan kelas model Kurt Lewin (dalam Wijaya Kusumah 2012:20) terdiri dari empat komponen, yaitu perencanaan (planning), pelaksanaan (acting), pengamatan (observating), perenungan (reflecing).

\section{Siklus 1}

Siklus pertama dlam PTK ini terdiri dari perencanaan, pelaksanaan, pengamatan dan refleksi sebagai berikut:

\section{Perencanaan (Planning)}

Peneliti melakukan analisis kurikulum untuk mengetahui kompetensi dasar yang akan disampaikan kepada siswa dengan menggunakan pembelajaran metode bermain.

a. Membuat rencana pembelajaran metode bermain.

b. Membut lembar kerja siswa.

c. Membuat instrumen yang digunakan dalam PTK.

\section{Pelaksanaan (Acting)}

a. Membagi siswa dalam bentuk kelompok.

b. Menyajikan materi pelajaraan.

c. Memberikan materi dalam bentuk bermain

d. Dalam melakukan aktivitas bemain, guru mengarahkan murid.

e. Melakukan pengamatan atau observasi.

\section{Pengamatan (Observation)}

a. Situasi kegiatan belajar mengajar.

b. Keaktifan siswa dalam peroses belajar.

\section{Refleksi (Reflecting)}

Peneliti mengadakan evaluasi dari kegiatan perencanaan, pelaksanaan dan observasi. Dari evaluasi dan refleksi siklus I digunakan sebagai acuan dalam penyusunan perencanaan pada siklus berikutnya yaitu siklus II sebagai upaya perbaikan.

\section{Siklus 2}

Seperti halnya siklus pertama, siklus keduapun terdiri dri perencanaan (Planning), pelaksanaan (Acting), pengamatan (Observation) dan refleksi (Reflecting).

\section{Perencanaan (Planning)}

Peneliti melakukan rencana pembelajaran berdasarkan hasil refleksi pada siklus pertama.

\section{Pelaksanaan (Acting)}

Guru melaksanakan pembelajaran Penjasorkes dengan metode bermain berdasarkan rencana pembelajaran hasil refleksi pada siklus pertama.

\section{Pengamatan (Observation)}

Peneliti melakukan pengamatan terhadap minat belajar siswa melalui metode bermain.

\section{Refleksi (Reflecting)}

Peneliti melakukan refleksi terhdap pelaksanaan siklus kedua dan menganalisis serta membuat kesimpulan atas pelaksanaan pembelajaran melalui metode bermain dalam peningkatan minat belajar siswa dalam pembelajaran Pendidikan Jasmani Olahraga dan Kesehatan di Sekolah Menengah Pertama.

\section{HASIL DAN PEMBAHASAN}

\section{A. Hasil Penelitian}

Setelah melakukan prosedur Penelitian Tindakan Kelas (PTK) yang dimulai dari membuat proposal, membuat lembaran instrumen dan menerapkan metode yang dibuat maka peneliti melaporkan hasil PTK. Peneliti juga telah melakukan teknik pengumpulan data, kemudian menganalisis data bersama obsever, mencoba menarik kesimpulan, menentukan tindakan perbaikan sesuai dengan hasil penelitian dan menentukan tindakan selanjutnya pada masing-masing siklus, maka pada bab ini peneliti akan menguraikan hasil penelitian yang telah dicapai dalam melaksanakan PTK.

\section{Pelaksanaan Siklus I \\ a. Tahap Perencanaan}

Perencanaan pada siklus I pada tanggal 23 Mei 2014, peneliti membuat rencana pelaksanaan pembelajaran sebagai berikut:

1) Peneliti melakukan analisis kurikulum untuk mengetahui kompetensi dasar yang akan disampaikan kepada siswa dalam pembelajaran Penjasorkes.

2) Membuat rencana pembelajaran yang mengacu pada tindakan yang diterapkan dalam PTK yaitu dengan pembelajaran melalui permainan.

3) Membuat sarana prasarana yang menunjang proses pembelajaran.

4) Menyusun lembar pengamatan pembelajaran.

5) Peneliti membuat lembaran instrumen.

\section{b. Tahap pelaksanaan tindakan}

Tahap pada pelaksanaan tindakan dilakukan dengan prosedur yang telah direncanakan pada tanggal 23 Mei 2014. Pada pertemuan ini jumlah

Meningkatkan Minat Belajar Siswa Dalam Pembelajaran .....37 Sefriadiansyah ${ }^{1}$, Eldawaty ${ }^{2}$ 
siswa yang hadir 32 orang dari 33 orang yang terdaftar dikelas VIII-4, satu orang siswa yang tidak hadir tanpa keterangan sedangkan observer sebagai kolaborator hadir keseluruhannya jumlahnya adalah dua orang.

\section{1) Pendahuluan}

Pada siklus ini proses pembelajaran berlangsung berdasarkan rencana pelaksanaan pembelajaran (RPP) yang telah ditetapkan. Didalam pelaksanaan pembelajaran Penjasorkes, langkah-langkah kegiatan pembelajaran atau proses pembelajaran yang akan dilakukan sebelumnya adalah mengumpulkan siswa untuk berbaris, berdo'a, absensi, merangsang pengetahuan awal siswa tentang materi tolak peluru gaya membelakang, peregangan, pemanasan, kegiatan inti dan kegiatan penutup.

Pelaksanaan pemanasan dilakukan dalam dua bentuk yaitu pemanasan umum dan pemanasan khusus. Dalam pemanasan umum guru memberikan bentuk-bentuk permainan yang menyenangkan tujuannya selain meningkatkan frekuensi jantung secara berlahan, juga untuk meningkatkan kesenangan siswa terhadap pembelajaran. Permainan tradisional yang penulis berikan dalam pemanasan umum yaitu permainan "Hitam-Hijau" sedangkan dalam pemanasan khusus dan kegiatan inti mengarahakan siswa ke materi tolak peluru dengan pendekatan bermain yang dimodifikasi.

\section{1) Pemanasan Umum}

Setelah siswa melakukan pereganggan selanjutnya siswa melaksanakan pemanasan umum. Pemanasan umum dilaksanankan permainan tradisional yaitu permainan "HitamHijau". Cara pelaksanaannya, siswa dibagi menjadi dua bebanjar yang saling berhadapan selanjutnya guru menentukan nama kepada kelompok. Kelompok pertama bernama hitam dan kelompok kedua bernama hijau. Apabila guru mengatakan hijau maka kelompok hitam mengejar kelompok hijau, begitupun sebaliknya. Target pengejaran yaitu lawan kelompok yang berada dihadapannya. Siswa diberikan waktu 30 detik untuk mengejar. Siswa yang berhasil adalah siswa yang mampu menangkap dan meloloskan diri dari pengejaran. Bagi siswa yang tertangkap dan tidak mampu menangkap akan mendapatkan hukuman sesuai dengan sepakatan bersama.

\section{2) Pemanasan khusus}

Setelah siswa melaksanakan pemanasan umum, siswa dikumpulkan kembali selanjutnya guru memberi penjelasan materi tentang tolak peluru gaya membelakang dengan pendekatan bermain. Dalam pemanasan khusus siswa melaksanakan kegiatan cara menolak dalam pendekatan bermain yang dimodifikasi. Tujuannya adalah selain meningkatkan kesenangan bagi siswa diharapkan siwa juga mampu menolak peluru secara baik dan benar.

a. Alat yang digunakan

Bola-bola kecil yang berwarna-warni sebanyak 50 bola dan patok digunakan untuk pembatas antara kelompok.

b. Pelaksanaannya

Siswa dibagi menjadi dua bagian terdiri dari dua kelompok yang jumlahnya sama banyak dan antara kelompok saling berhadapan satu sama lainnya. Jarak antara kelompok sekitar dua atau tiga meter. Selanjutnya guru membagikan bolabola kecil kepada masing-masing kelompok. Apabila guru telah memberikan aba-aba "ya", masing-masing kelompok harus menolak peluru kekelompok yang lain sebanyak mungkin.

Pemenang ditentukan oleh kelompok yang berhasil mempertahankan kawasannya dari serangan. Kelompok yang kalah yaitu kelompok yang tidak bisa melindungi kwasan atau memiliki bola terbanyak dikawasannya. Guru memberikan hukuman kepada kelompok yang kalah sesuai dengan kesepakatan kelompok yang menang. Proses pelaksanaan pemanasan khusus dengan permainan modifikasi dapat dilihat pada cuplikan atau gambar berikut ini:

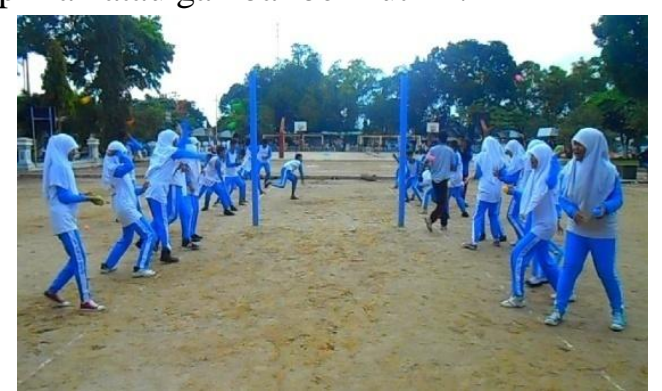

\section{Gambar 7. Pelaksanaan Pemanasan Khusus dengan Permainan Modifikasi}

\section{2) Kegiatan Inti}

Setelah melaksanakan pemanasan khusus, siswa dikumpulkan kembali selanjutnya memberi penjelasan tentang kigiatan inti. Didalam kegiatan inti, siswa melaksanakan kegiatan pembelajaran dengan permainan tolak peluru yang dimodifikasi yaitu permainan "Lempar Sasaran”. Tujuan permainan ini yaitu melatih

Meningkatkan Minat Belajar Siswa Dalam Pembelajaran .....38 Sefriadiansyah $^{1}$, Eldawaty ${ }^{2}$ 
siswa dalam menolak dan melatih siswa mengarakan peluru kearah sasaran. Kegiatan inti dilakukan dengan perlombaan antara kelompok.

c. Alat yang digunakan

Peluru yang dimodifikasi, kardus dan patok.

d. Pelaksanaannya

Siswa dibagi menjadi enam kelompok, terdiri dari tiga kelompok laki-laki dan tiga kelompok perempuan yang jumlahnya sama banyak. Selanjutnya guru membagikan peluru yang dimodifikasi dan kardus kepada masingmasing kelompok, jarak kardus dengan kelompok antar 1-2 meter dan jarak kardus antara garis finish kurang lebih satu meter. Apabila guru telah memberikan aba-aba "ya", maka masing-masing kelompok berusaha melempar kardus dengan peluru yang dimodifikasi. Pemenang ditentukan oleh kelompok yang mampu melempar kardus melewati garis finish. Proses pelaksanaan kegiatan inti dengan permainan modifikasi lempar sasaran dapat dilihat pada cuplikan atau gambar berikut ini:

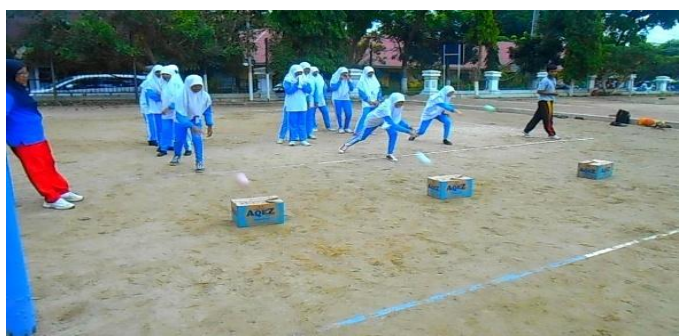

Gambar 8. Pelaksanaan Kegiatan Inti dengan Permainan Modifikasi Lempar Sasaran

\section{3) Kegiatan Penutup}

Pada kegiatan penutup siswa dikumpulkan dan dibariskan kemudian guru mengevaluasi hasil pembelajaran yang telah dilaksanakan serta memberikan solusi tentang materi yaang belum dipahami siswa selanjutnya do'a penutup dan terakhir siswa dibubarkan.

\section{c. Tahap pengamatan}

Selama proses pembelajaran berlangsung guru dan kolaborator melakukan penilaian proses dan pengamatan terhadap kegiatan siswa. Aspek yang diamati selama proses pembelajaran berlangsung yaitu gerak siswa dalam melaksanakan permainan terlibat aktif atau tidak, kerja sama siswa dan kedisiplinannya.

Persentase $=\frac{\Sigma \text { Skor yang diperoleh }}{\Sigma \text { siswa }} \times 100 \%$

Siswa bergerak aktif $=\frac{13}{32} \times 100 \%=40,6 \%$
Siswa bergerak kurang aktif $=\frac{19}{32} \times 100 \%=$ $59,4 \%$

Siswa berkerja sama baik $=\frac{21}{32} \times 100 \%=65,6 \%$

Siswa berkerja sama kurang baik $=\frac{11}{32} \times 100 \%=$ $34,4 \%$

Siswa berdisiplin baik $=\frac{25}{32} \times 100 \%=78,1 \%$

Siswa berdisplin kurang baik $=\frac{7}{32} \times 100 \%=$ $21,9 \%$

Data hasil pengamatan diatas menunjukan bahwa siswa yang bergerak aktif prsentasenya adalah $40,6 \%$ siswa bekerja sama baik adalah $65,6 \%$ dan siswa berdisiplin baik adalah $78,1 \%$. Berdasarkan hasil pengamatan terhadap proses kegiatan pembelajaran Penjasorkes tersebut diperoleh rata-rata $61,4 \%$ pada siklus I pertemuan satu.

Setelah siswa melesaikan pembelajaran, guru membagikan angket tentang pembelajaran yang telah dilaksanakan pada siklus I. Hasil pengukuran minat belajar siswa diolah dengan menggunakan penskoran skala Likert dengan maksud agar guru mengetahui kinerja guru terutama minat belajar siswa terhadap pembelajaran Penjasorkes.

Berdasarkan tabel analisis data minat belajar siswa terhadap pembelajaran Penjasorkes diatas diperolehan rata-rata 48,7 ( jumlah skor semua siswa dibagi julmlah siswa dikelas) sehingga dapat ditentukan bahwa minat belajar siswa dikelas VIII-4 pada siklus I dikategorikan sangat tinggi (sangat baik). Penentuan kategori hasil pengukuran minat kelas dapat dilihat pada tabel berikut ini:

Tabel 5. Kategori Minat Kelas untuk 15 Butir Pernyataan dengan Rentang Skor 15 Sampai 60

\begin{tabular}{|c|c|c|}
\hline No & Skor siswa & Kategori minat \\
\hline 1 & $\begin{array}{c}\text { Lebih dari } \\
48\end{array}$ & Sangat tinggi/sangat baik \\
\hline 2 & $\begin{array}{c}42 \text { sampai } \\
47\end{array}$ & Tinggi/baik \\
\hline 3 & $\begin{array}{c}30 \text { sampai } \\
41\end{array}$ & Rendah/kurang \\
\hline 4 & $\begin{array}{c}\text { Kurang dari } \\
30\end{array}$ & Sangat rendah/sangat kurang \\
\hline
\end{tabular}

\section{d. Tahap refleksi}

Berdasarkan data hasil pengamatan terhadap pelaksanaan proses pembelajaran pada siklus ini terdapat temuan-temuan sebagai berikut:

Meningkatkan Minat Belajar Siswa Dalam Pembelajaran ....39 Sefriadiansyah $^{1}$, Eldawaty ${ }^{2}$ 
1) Tingkat siswa yang begerak aktif masih rendah yaitu sebanyak 13 siswa terlibat aktif dan 19 siswa yang masih kurang aktif.

2) Kerja sama siswa sangat bagus yaitu siswa yang berkerja sama baik sebanyak 21 siswa dan siswa yang kurang bekerja sama sebanyak 11 orang siswa.

3) Disiplin siswa diperoleh sebanyak 25 siswa yang berdisiplin baik dan 7 orang siswa yang disiplinnya kurang baik.

4) Analisis minat belajar siswa diperoleh ratarata 48,7 dengan kategori minat belajar siswa dikelas VIII-4 adalah sangat tinggi/sangat baik.

\section{Pelaksanaan siklus II}

Siklus II merupakan tindakan perbaikan dari siklus sebelumnya tetapi didalam siklus ini terdapat perbedaan permainan, tujuannya adalah agar siswa tidak jenuh terhadap pembelajaran dan minat siswa terhadap pembelajaran diharapkan akan terus meningkat. Pada siklus II ini, permainan yang diberikan lebih diarahkan kepada materi tolak peluru gaya membelakang sehingga pada akhirnya siswa mampu melakukan tolak peluru gaya membelakang secara benar.

\section{a. Tahap perencanaan}

Siklus kedua dilaksanakan tanggal 6 juni 2014 dengan banyak siswa 33 orang dan dua orang kabolator. Adapun perecanaan tindakan pada siklus II ini adalah sebagai berikut:

1) Membuat rencana pelaksanaan pembelajaran (RPP) yang dikembangkan berdasarkan kebutuhan penulisan laporan yang digunakan dalam penelitian.

2) Membuat instrumen yang digunakan dalam siklus PTK.

3) Menyiapakan media yang diperlukan untuk membantu pengajaran agar proses pelaksanaan pembelajaran dapat berjalan dengan lancar.

4) Menyusun lembar pengamatan pembelajaran.

5) Memperbaiki permainan agar lebih efektif dalam proses pelaksanaan pembelajaran.

\section{b. Tahap pelaksanaan}

Pelaksanaan tindakan dilakukan dengan prosedur yang telah direncanakan pada tanggal 6 juni 2014. Pada pertemuan ini siswa VIII-4 hadir keseluruhannya dan observer sebagai kolaborator yang hadir adalah dua orang.

\section{1) Pendahuluan}

Pada siklus ini proses pembelajaran berlangsung berdasarkan rencana pelaksanaan pembelajaran (RPP) yang telah ditetapkan.
Didalam pelaksanaan pembelajaran Penjasorkes, langkah-langkah kegiatan pembelajaran yang akan dilakukan sama dengan siklus sebelumnya yaitu mengumpulkan siswa untuk berbaris, berdo'a, absensi, merangsang kembali pengetahuan siswa tentang materi tolak peluru gaya membelakang, peregangan, pemanasan umum, pemanasan khusus, kegiatan inti dan kegiatan penutup.

Perbedaan pada siklus sebelumnya adalah dari pelaksanaan pemanasan umum, pemanasan khusus dan kegiatan inti. Semua kegiatan tersebut dilakukan dengan permainan yang berbeda agar anak tidak jenuh terhadap pembelajaran. Permainan yang diberikan lebih diarahkan sehingga siswa mampu melaksanakan tolak peluru gaya membelakang secara baik dan benar. Didalam pemanasan umum pada siklus ini adalah permainan tradisional yaitu permainan "Angka Bergulir" sedangkan dalam pemanasan khusus dan kegiatan inti lebih mengarahakan siswa kepada materi tolak peluru gaya membelakang dengan pendekatan bermain yang dimodifikasi.

\section{- Pemanasan Umum}

Setelah siswa melakukan pereganggan selanjutnya siswa melaksanakan pemanasan umum. Pemanasan umum dilaksanankan dengan bentuk permainan berupa permainan tradisional yaitu permainan "Angka Bergulir". Cara pelaksanaannya, siswa dibagi menjadi enam kelompok, terdiri dari tiga kelompok laki-laki dan tiga kelompok perempuan. Setiap kelompok berbaris sehingga membentuk enam baris sejajar. Selanjutnya guru memberikan nama kelompok sesuai dengan urutan satu sampai urutan enam.

Guru bertugas memberikan aba-aba, apabila aba-aba satu dan dua, maka kelompok satu pindah kekelompok dua dan kelompok dua pindah kekelompok satu. Selanjutnya apabila guru menyebutkan kelompok tiga dan enam, maka kelompok tiga akan pindah kekelompok enam dan kelompok enam akan pindah kekelompok tiga, begitu seterusnya. Dengan catatan kelompok yang pindah akan berubah nama kelompoknya sesuai dengan kelompok yang ditempatinya.

Guru akan memberikan hukuman apabila siswa terlambat bergerak atau salah dalam menanggapi perintah yang diberikan oleh guru. Hukuman yang diberikan berupa push up, lompat atau bernyanyi sesuai dengan kesepakatan bersama. Proses pelaksanaan pemanasan umum dengan permainan tradisional angka bergulir

Meningkatkan Minat Belajar Siswa Dalam Pembelajaran .....40 Sefriadiansyah ${ }^{1}$, Eldawaty ${ }^{2}$ 
dapat dilihat pada cuplikan atau gambar berikut ini:

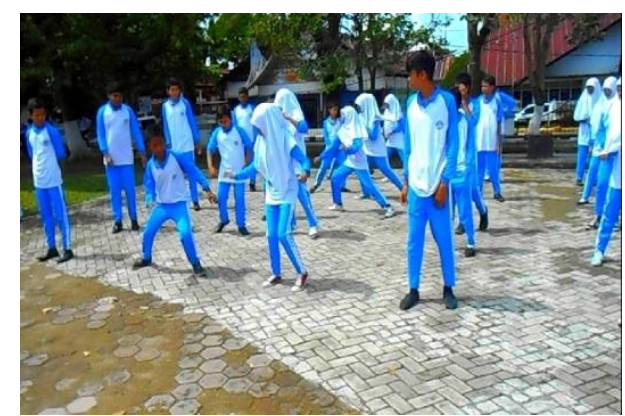

\section{Gambar 9. Pelaksanaan Pemanasan Umum dengan Permainan Tradisional Angka Bergulir}

\section{- Pemanasan Khusus}

Setelah siswa melaksanakan pemanasan umum, siswa dikumpulkan kembali selanjutnya memberi penjelasan materi tentang tolak peluru gaya membelakang dengan pendekatan bermain. Dalam pemanasan khusus siswa hanya melaksanakan kegiatan cara meluncur atau fase awal dalam melaksanakan tolak perluru dengan gaya membelakang (obrient) dalam bentuk bermain. Tujuannya pemanasan khusus ini adalah supaya siswa dapat melaksanakan fase awal secara baik dan benar.

e. Alat yang digunakan

Botol mineral yang berisikan pasir sebanyak empat botol, sebagai peluru yang dimodifikasi dan patok digunakan untuk membatasi pergerakan sisiwa.

\section{f. Cara pelaksanaannya}

Siswa dibagi menjadi empat kelompok, terdiri dari dua kelompok laki-laki dan dua kelompok perempuan. Satu kelompok terdiri 7 sampai 9 orang siswa setiap kelompok dipisahakan menjadi dua bagian yang saling berhadapan, jaraknya kurang lebih sekitar empat meter. Selanjutnuya guru membagikan peluru yang dimodifikasi kepada masing-masing kelompok.

Apabila guru telah memberikan aba-aba "ya", siswa yang didepan harus meluncur atau melakukan fase awal dari tolak peluru dan belari menghampiri teman kelompok yang berada didepannya dengan memberikan peluru tesebut selanjutnya siswa yang mendapatkan peluru, berlari lagi seperti yang dilakukan oleh teman sebelumnya dan begitu seterusnya sampai semua siswa mendapatkan giliran yang sama. Guru memberikan hukuman kepada kelompok yang terlambat atau asal-asalan dalam melaksanakan kegiatan. Proses pelaksanaan pemanasan khusus dengan permainan modifikasi dapat dilihat pada cuplikan atau gambar berikut ini:

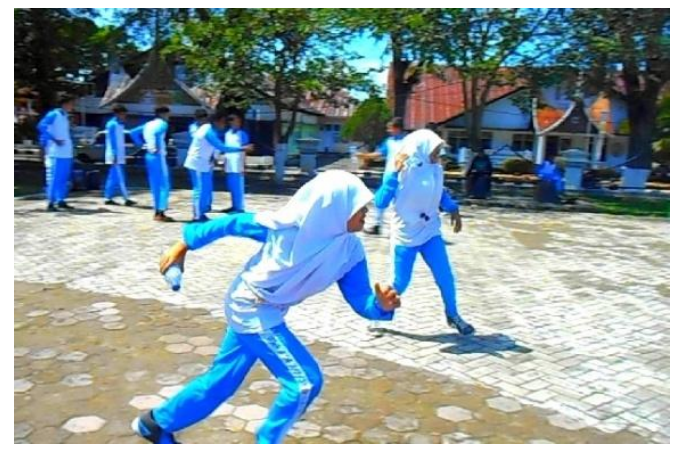

\section{Gambar 10. Pelaksanaan Pemanasan Khusus dengan Permainan Modifikasi}

\section{2) Kegiatan Inti}

Setelah melaksanakan pemanasan khusus, siswa dikumpulkan kembali, selanjutnya memberi penjelasan tentang kigiatan inti yang akan dilakukan. Didalam kegiatan inti, siswa melaksanakan kegiatan mulai dari fase awal sampai ke fase utama dari tolak peluru. Kegiatan inti dilakukan dengan permainan modifikasi. Permainan yang dilakukan berbeda dengan siklus sebelumnya agar siswa tidak jenuh terhadap pembelajaran. Pada siklus ini permainan lebih diarahkan kepada kemampuan siswa dalam melaksanakan tolak peluru gaya membelakang (obrient). Pelaksanaan kegiatan dilaksanakan dengan perlombaan antara kelompok.

g. Alat yang digunakan

Botol mineral yang berisikan pasir sebanyak empat botol, sebagai peluru yang dimodifikasi, patok sebagai pembatas gerak siswa dan kardus sebagai target atau sasaran dalam pelaksanaan kegiatan.

h. Cara pelaksanaannya

Jumlah kelompok sama dengan pelaksanaan kegiatan sebelumnya. Masing-masing kelompok berbaris rapi sesuai dengan patok yang telah ditentukan dan posisi kelompok mengadap kekardus yang telah disediakan, selanjutnya guru membagikan peluru yang telah dimodifikasi kepada setiap kelompok. Masing-masing kelompok memperoleh satu peluru dan jarak kardus dengan kelompok antar 2-3 meter. Apabila guru telah memberikan aba-aba "ya", maka masing-masing kelompok melakukan kegiatan dengan menggunakan fase awal sampai kepada fase utama dalam tolak peluru dengan menggunakan awalan gaya membelakang (obrient). 
Selanjutnya siswa melakukan tolakan kearah kardus yang berada didepan kelompok setelah melakukan tolakan, siswa tersebut mengambil kembali peluru serta memberikan peluru kepada teman kelompok yang berada dibelakangnya, teman yang memperoleh peluru tersebut melakukan kegiatan seperti yang dilakukan teman sebelumnya dan begitu seterusnya. Proses pelaksanaan kegiatan inti dengan permainan modifikasi dapat dilihat pada cuplikan atau gambar berikut ini:

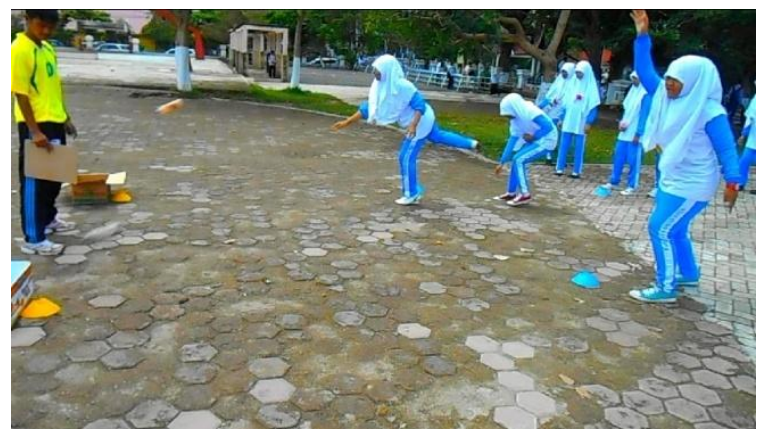

Gambar 11. Pelaksanaan Kegiatan Inti dengan Permainan Modifikasi

Apabila peluru masuk kedalam kardus, maka kelompok akan mendapatkan angka atau point satu. Pemenang ditentukan oleh angka yang diperoleh oleh kelompok, semakin banyak peluru yang masuk kedalam kardus maka semakin besar peluang menang bagi kelompok. Kelompok yang kalah akan mendapatkan hukuman sesuai dengan kesepakatan kelompok yang menang.

\section{3) Kegiatan penutup}

Pada kegiatan penutup siswa dikumpulkan dan dibariskan kemudian guru mengevaluasi hasil pembelajaran yang telah dilaksanakan serta memberikan solusi tentang materi yang belum dipahami siswa selanjutnya ditutup dengan do'a penutup dan terakhir siswa dibubarkan.

\section{c. Tahap pengamatan}

Pegamatan terhadap proses pembelajaran yang berlangsung pada siklus kedua oleh guru dan kolaborator. Intrumen yang digunakan berupa lembar observasi yang telah disedikan seperti pada siklus pertama.

Aspek yang diamati selama proses pembelajaran berlangsung sama dengan siklus pertama.

Persentase $=\frac{\Sigma \text { Skor yang diperoleh }}{\Sigma \text { siswa }} \times 100 \%$
Siswa bergerak aktif $=\frac{25}{33} \times 100 \%=75,8 \%$
Siswa bergerak kurang aktif $=\frac{8}{33} \times 100 \%=$ $24,2 \%$

Siswa berkerja sama baik $=\frac{26}{33} \times 100 \%=78,8 \%$

Siswa berkerja sama kurang baik $=\frac{7}{33} \times 100 \%=$ $21,2 \%$

Siswa berdisiplin baik $=\frac{30}{33} \times 100 \%=90,9 \%$

Siswa berdisplin kurang baik $=\frac{3}{33} \times 100 \%=$ $9,1 \%$

Data hasil pengamatan diatas menunjukan bahwa siswa yang bergerak aktif prsentasenya adalah $75,8 \%$ siswa bekerja sama baik adalah $78,8 \%$ dan siswa berdisiplin baik adalah $9,1 \%$ Berdasarkan hasil pengamatan terhadap proses kegiatan pembelajaran Penjasorkes tersebut diperoleh rata-rata $81,8 \%$ pada siklus II pertemuan dua.

Setelah siswa melesaikan pembelajaran, guru membagikan angket tentang pembelajaran yang telah dilaksanakan pada siklus II. Hasil pengukuran minat belajar siswa diolah dengan menggunakan penskoran skala Likert dengan maksud agar guru mengetahui kinerja guru terutama minat belajar siswa terhadap pembelajaran Penjasorkes, butir angket dan analisis datanya sama dengan siklus sebelumnya.

Berdasarkan tabel diatas analisis data minat belajar siswa terhadap pembelajaran Penjasorkes diperolehan rata-rata 49,2 (jumlah skor semua siswa dibagi julmlah siswa dikelas) sehingga dapat ditentukan bahwa minat belajar siswa dikelas VIII-4 pada siklus II dikategorikan sangat tinggi (sangat baik). Penentua kategori minat kelas siswa dapat dilihat pada siklus sebelumnya.

\section{d. Tahap refleksi}

Berdasarkan data hasil pengamatan terhadap pelaksanaan proses pembelajaran pada siklus ini terdapat temuan-temuan sebagai berikut:

1) Terdapat peningkatan terhadap gerak siswa yaitu siswa yang begerak aktif sebanyak 25 siswa dan siswa yang masih kurang aktif sebanyak 8 siswa.

2) Kerja sama siswa meningkat yaitu siswa yang berkerja sama baik sebanyak 26 siswa dan siswa yang kurang dalam bekerja sama sebanyak 7 orang siswa.

3) Disiplin siswa meningkat sebanyak 30 siswa yang berdisiplin baik dan 3 orang siswa yang disiplinnya masih kurang baik.

4) Analisis minat belajar siswa diperoleh ratarata 48,7 dengan kategori minat belajar 
siswa dikelas VIII-4 adalah sangat tinggi/sangat baik.

\section{B. Pembahasan dan Pengambilan \\ Kesimpulan}

Berdasarkan hasil penelitian yang telah dilaksanakan maka hasil penelitian siklus I dan siklus II dapat dipresentasikan Data tersebut menunjukan bahwa terjadi peningkatan 20,4\% dari siklus I ke siklus II. Peningkatan kegiatan pembelajaran Penjasorkes dikelas VIII-4 SMP Negeri 2 Batusangkar dilaksanakan selama dua siklus melalui penelitian tindakan kelas dapat dilihat melalui gerafik berikut ini:

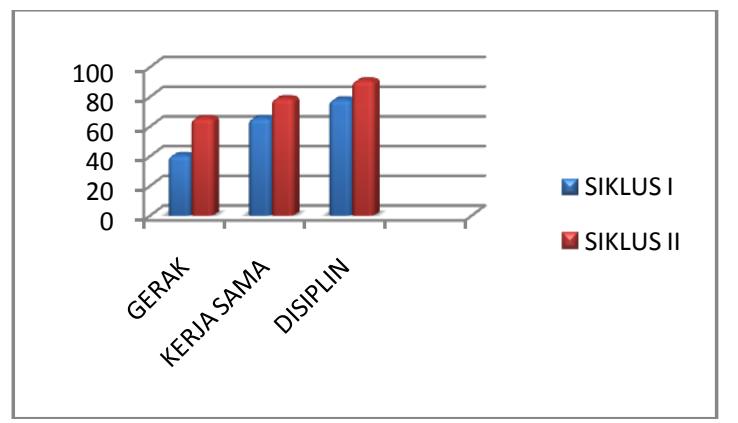

Grafik 1. Kegiatan Belajar Siswa dalam

Proses Pembelajaran Penjasorkes

Berdasarkan analisis data minat belajar siswa terhadap proses pembelajaran Penjasorkes siklus I dan siklus II maka dapat dijelaskan melalui tabel berikut ini:

Tabel 9. Data Hasil Analisis Minat Belajar Siswa Siklus I dan Siklus II

\begin{tabular}{|c|c|c|c|}
\hline No & Siklus & $\begin{array}{c}\text { Rata- } \\
\text { rata }\end{array}$ & Kategori Minat \\
\hline 1 & I & 48,7 & $\begin{array}{c}\text { Sangat Tinggi/Sangat } \\
\text { baik }\end{array}$ \\
\hline 2 & II & 49,2 & $\begin{array}{c}\text { Sangat Tinggi/Sangat } \\
\text { baik }\end{array}$ \\
\hline
\end{tabular}

Dari tabel diatas menunjukan bahwa minat kelas siswa pada siklus I diperoleh rata-rata 48,7 dan pada siklus II diperoleh rata-rata 49,2 sehingga minat kelas siswa pada siklus I dan siklus II dikategorikan sangat tinggi (sangat baik). Peningkatan minat belajar siswa dalam proses pembelajaran dikelas VIII-4 SMP 2 Batusangkar dapat lebih jelas terlihat pada grafik berikut ini:

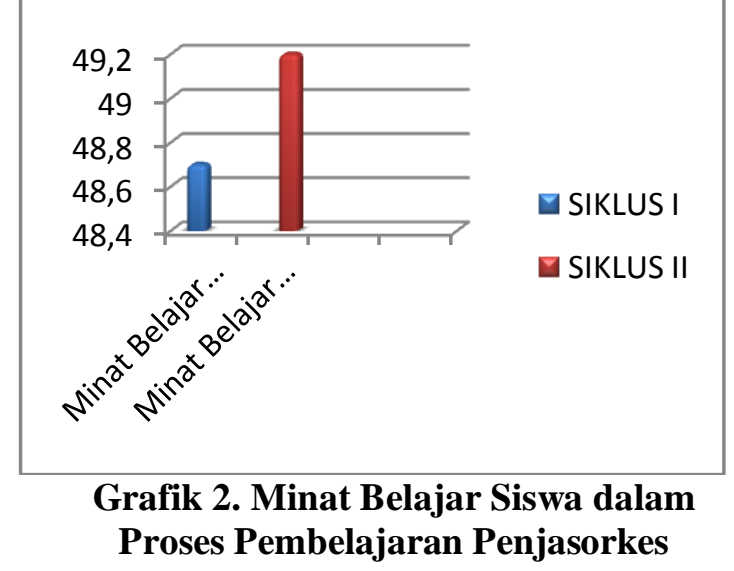

Berdasarkan dari data hasil pengamatan dan analisis data minat belajar siswa terhadap kegiatan pembelajaran dengan demikian dapat disimpulkan bahwa, pembelajaran Penjasorkes melalui metode bermain dalam upaya meningkatkan minat belajar siswa dikelas VIII-4 SMP Negeri 2 Batusangkar dikatakan berhasil.

\section{KESIMPULAN}

Berdasarkan analisis terhadap data hasil penelitian tindakan kelas ini, disimpulakan bahwa penerapan metode bermain dapat meningkatkan minat belajar siswa dalam proses pembelajaran Penjasorkes dikelas VIII-4 SMP Negeri 2 Batusangkar semester genap tahun pelajaran 2013/2014. Peningkatan minat belajar siswa dalam proses pembelajaran Penjasorkes ini terlihat dari hal-hal berikut ini:

1. Proses pembelajaran dengan metode bermain mendapat tanggapan yang positif dari siswa karena dianggap sangat menarik, menyenangkan, membuat siswa lebih aktif dalam bergerak dan membangkitkan keinginan siswa untuk belajar.

2. Aktivitas gerak siswa dalam pembelajaran sangat baik, ini dapat dilihat dari peningkatan gerak siswa mencapai $75,7 \%$.

3. Kerjasama siswa dalam kegiatan pembelajaran sangat baik, terlihat dari kerjasama siswa yang meningkat mencapai $78,8 \%$ serta disiplin siswa meningkat yaitu mencapai $90,9 \%$.

4. Dari hasil observasi yang dilakukan, terlihat bahwa terjadinya peningkatan dalam proses pembelajaran, pada siklus satu diperoleh rata-rata $61,4 \%$ dan siklus dua diperoleh rata-rata $81,8 \%$. Ini menunjukan bahwa terjadinya peningkatan $20,4 \%$ dari siklus I ke siklus II. 
5. Analisis minat belajar siswa menunjukan bahwa kategori minat belajar siswa dikelas VIII-4 adalah sangat tinggi/sangat baik.

Berdasarkan uraian diatas dapat disimpulkan bahwa minat belajar siswa dalam pembelajaran tergolong tinggi dan penerapan metode bermain berhasil meningkatkan minat siswa dalam proses pembelajaran Penjasorkes dikelas VIIII-4 SMP Negeri 2 Batusangkar.

\section{DAFTAR PUSTAKA}

Amperelvy, Yulita 2007. Meningkatkan Keseimbangan Berjalan melalui Permainan Berjalan Diatas Jejak Kaki Bagi Anak Tuna Grahita Sedang Kelas D.I SKB Karya Padang. Padang: FIP UNP.

Daniel, Nurafdi. 2008. Hubungan Minat dengan Tingkat Kesegaran Jasmani terhadap Hasil Belajar Penjasorkes Siswa Putir di SMA PGRI Kota Sawahlunto. Padang: FIK UNP.

Effendi, Mawardi. 2010. Istilah-Istilah dalam Peraktek Mengajar dan Pembelajaran. Padang: UNP Press.

Gusti Regina, Monica. 2012. Pengaruh Metode Pembelajaran Kooperatif Tipe Tink-PairShare Untuk Meningkatkan Minat Belajar Siswa. Teknik Elektronika. FT UNP.

Hamzah. 2012. Teori Motivasi dan Pengukurannya Analisis di Bidang Pendidikan. Jakarta: Bumi Aksara.

Kusumah, Wijaya dan Dedi Dwitagama. 2012. Mengenal Penelitian Tindakan Kelas. Jakarta: PT. Indeks.

Kunandar. 2010. Langkah Mudah Menulis Penelitian Tindakan Kelas sebagai Pengembangan Profesi Guru. Jakarta: PT. Rajawali Pers

Kharanis dan Darnis Arif. 2000. Perkembangan Dan Belajar Peserta Didik. UNP.

Majid, Abdul. 2012. Perencanaan Pembelajaran Mengembangkan Standar Guru. Bandung: Remaja Rosdakarya.

Muslich, Masnur. 2010. Bagaimana menulis sikripsi?. Jakarta: Bumi Askara.
Meilinda. 2009. Meningkatkan Minat Belajar Sejarah Siswa melalui Pembelajaran Kooperatif Teknik Time Token. FIS UNP.

Nurani Sujiono, Yuliani dan Bambang Sujiono. 2010. Bermain Kreati Berbasis Kecerdasan Jamak. Jakarta: PT. Indeks.

Patusari, Achmad. 2012. Manejemen Pendidikan Jasmani dan olahraga. Jakarta: PT. Rineka Cipta.

Rosdiani, Dini. 2012. Dinamika Olahraga dan Pengembangan Nilai. Bandung: Alfabeta.

Sardiman. 2001. Interaksi dan Motivasi Belajar Mengajar. Jakarta: PT Raja Grafido Persada.

Sentosa, Ria. 2009. Meningkatkan Minat Membaca Anak melalui Permainan TekaTeki Silang dengan Gambar Binatang di TK Indah Jelita Payakumbuh. FIP UNP.

Warlina, Reni. 2008. Upaya Meningkatkan Minat Membaca Anak melalui Permainan Kotak Pintar di TK Aisyiyah Suliki Kabupaten Lima Puluh Kota. FIP UNP. 